\title{
Urgences
}

\section{La bougie}

\section{Louise Beauchamp}

Numéro 27, mars 1990

Images imaginaires

URI : https://id.erudit.org/iderudit/025566ar

DOI : https://doi.org/10.7202/025566ar

Aller au sommaire du numéro

Éditeur(s)

Urgences

ISSN

0226-9554 (imprimé)

1927-3924 (numérique)

Découvrir la revue

Citer ce document

Beauchamp, L. (1990). La bougie. Urgences, (27), 14-17.

https://doi.org/10.7202/025566ar d'utilisation que vous pouvez consulter en ligne.

https://apropos.erudit.org/fr/usagers/politique-dutilisation/ 


\section{La bougie \\ Louise Beauchamp}

J'abdique haut et fort ton nom, les syllabes en ta forme, les rondeurs et la proéminence aimée. Obscène d'amour. Ce sont tes mains parfaites qui préfigurent le chant à venir. Elles courent près de ma bouche, sur ma lèvre supérieure. Voilà libérées les premières émanations hostiles aux lumières. 
La pièce est sombre, la scène éclairée à peine. Je suis entrée et des lampions brûlaient, madrigales et tambourins, une messe vieille. Le feu que j'ai allumé ne voulait pas pour nous consumer. La mèche noyée dans la cire exhale forte fumée, nous fermons les yeux 
16

Presque arrivée à la fin, de travers sous tes aisselles volantes. Il faut savoir s'échapper, jeter un regard du dessus, comme quand la mort nous emporte et choisir volontairement de revenir pour marier l'odeur aux odeurs. 
Malheureusement, les mots n'ont pas d'odeur. Peu importe la forme qu'on leur donne, ils sentent l'encre et le papier mêlés, quelques minutes, avant de sécher. Ce qu'il en reste plus tard, c'est l'odeur des livres, bonne, mais ce n'est pas la tienne. 